\title{
SERVICES QUALITY AND IMAGES: SATISFACTION AND LOYALTY OF STUDENTS FACE TO FACE TUTORIAL SERVICES
}

\author{
Yusuf ${ }^{1 *}$ \\ ${ }^{1}$ Universitas Terbuka, Tanjung Pinang, Indonesia
}

\begin{abstract}
Purpose of the study is to describe service quality, image, satisfaction and loyalty, and its direct and indirect influence. Using descriptive quantitative method with the descriptive and explanatory survey. The sample is 205 students. The type of primary data used and data analysis techniques using analysis tests path. The results showed that all the average variables were high and the image variable had the highest average. Directly, service quality to satisfaction, image to satisfaction, and satisfaction with loyalty have a significant effect, satisfaction with loyalty and image of loyalty has no significant effect. Simultaneously, service quality and image of satisfaction and service quality, image, satisfaction with loyalty have a significant effect. Indirectly, satisfaction can mediate service quality towards loyalty and satisfaction capable of mediating the image of loyalty. In its implications, any increase or decrease in satisfaction indirectly will influence the loyalty of Regional Office of Open University at Pangkalpinang tutorial students.
\end{abstract}

Keywords: Face-To-Face Tutorial, Image, Student Satisfaction, Service Quality, Student Loyalty

\section{INTRODUCTION}

At present, education is a growing industry in Asia, where many offer a variety of higher education programs and skills courses. Supported again with relative prices and very good quality. Currently leading universities from the UK and Australia set up branch campuses in Asia, while other universities from the United States, Canada, Australia, France, Germany, and New Zealand also offer the same programs with degrees in the field of study. (Bakar, Talib, \& Hashim, 2014). One area in the service literature that is of much concern is the conceptualization of service quality. In education, service quality is usually referred to as non-academic aspects of the consumer experience in an institution. (Khoo, Ha, \& McGregor, 2017) In the hospitality industry, service quality is also a point of differentiation among competitors and plays a very important role in increasing efficiency and effectiveness, and increasing the profitability of institutions. (Ali, Hussain, \& Ryu, 2017). Service quality is recognized as an important problem for businesses in improving the performance of service-based organizations, such as hotels, education, transportation, and restaurants which must also be managed effectively. (Kensbock, Patiar, \& Jennings, 2017).

A good company must consistently respond to customer complaints. Service quality is always updated and is considered to have a significant influence on the service sector that has high contact. However, the idea of service quality is often associated with the concept of a service company image and has become important in online banking services. (Saleh, Quazi, \& Keating, 2016). The image will rise when consumers get high service and will decrease when consumers get low service. Brand reputation is defined as a perception of the quality associated with the brand. (Nguyen \& LeBlanc, 2001).

The concept of service quality is a very complex discussion because the quality of service has a very different character when compared to the quality of the product, this is because services have properties that are not real. (Tjiptono, 2014). In the restaurant industry, customers not only evaluate food quality but also the quality of service they

* Corresponding author. Email address: yusuf_se@ecampus.ut.ac.id 
encounter during a dining experience. Perception quality of service is the main core determinant of customer satisfaction and behavior. (Omar, Ariffin, \& Ahmad, 2016). In the service of higher education, students not only feel a moment but as long as students take education. (Yusuf, 2016). However, the extent to which the perception of service quality, perceived value, satisfaction and loyalty are connected in the literature. (Wantara, 2016).

Student satisfaction is very important in the evaluation of distance learning because it is related to the quality of online learning and the process of student performance. Interaction is an important indicator of determining student satisfaction. (Harsasi \& Sutawijaya, 2018). The performance of Open University services is now different. In the past, the image inherent as an institution was difficult for students to quickly complete their education. This is due to many limitations. Students consider the distance learning system to be very difficult, especially as academic support facilities are not complete as they are today. (Susanto, 2014). Since 2008, service quality has continued to be improved, equipped and improved. Starting from the implementation of a quality assurance system, ISO 9001:2008 standard service disintegrated service patterns, friendliness of staff, development of independent learning facilities, technology facilities, increased accreditation, and others. (Purwaningdiyah, 2010). UT has been awarded international quality certificates by ICDE since 2005 and the International Organization for Standardization - ISO 9001 since 2006. Besides, all study programs at UT have also been accredited by the National Accreditation Board for Indonesian Higher Education. (Darojat, 2018).

Regional Office of Open University at Pangkalpinang Institution wants to study scientifically, whether the services that have been carried out affect the image of the institution. Regional Office of Open University at Pangkalpinang wants to periodically measure the effectiveness of all system improvements, among others on service management systems, satisfaction and loyalty carried out on the image of the Open University as an institution of higher education services open to all. Research this is by capturing perceptions of various groups of students who take part in the Face-to-Face Tutorial service.

\section{LITERATURE STUDY}

Ghozali (2010), entitled Analysis of the Quality of Education Services and Their Effects on Student Loyalty in Private Universities in the City of Semarang. The study was conducted at Private Universities in the City of Semarang to determine the relationship between the variable Image, Quality of Education Services, Student Satisfaction, and Loyalty of private tertiary institutions in the City of Semarang. The study used a cross-sectional research method with a sample of 100 respondents. The conclusion is that service quality variables affect student satisfaction variables and image variables can also affect student satisfaction at private universities in the city of Semarang.

Prasetyaningrum (2009), with the title analysis of the effect of learning and service quality on student satisfaction and student loyalty (Case study on Ungaran undergraduate students). This study uses a survey method with the sampling method in this study is purposive sampling. The population of the study was Ungaran Undaris students which began in the 2004/2005 academic year to 2008/2009 with a sample of 150 students. The conclusion is that student loyalty can be increased by improving the quality of learning that will increase student satisfaction. Student loyalty can also be improved by increasing the quality of services that will increase student satisfaction.

Research conducted by Sugihartono (2009), entitled the analysis of the influence of image, service quality and satisfaction on customer loyalty (Case Study at PT. Pupuk Kalimantan Timur, Grobogan Regency Sales Representative). The study was conducted on 102 companies in Central Java who are consumers of PT. Pupuk Kalimantan Timur, in Grobogan Regency, Central Java, is targeting the company's 


\section{SERVICES QUALITY AND IMAGES: SATISFACTION AND LOYALTY OF STUDENTS FACE TO FACE TUTORIAL SERVICES}

Sales Representatives. This study aims to analyze the effect of imagery on loyalty, analyze the effect of service quality on loyalty and analyze the effect of consumer satisfaction on the loyalty of urea fertilizer users produced by PT. East Kalimantan Fertilizer, in Grobogan Regency. The conclusion is that customer loyalty is positively influenced by image, service quality and company reputation. The better the image, service quality and company reputation, customer loyalty will also increase.

Stephen, et al, (2007), in his study entitled The Effect of brand image on overall satisfaction and loyalty in the context of color selection of cosmetic products. The study used data collection techniques using a questionnaire. The instruments are arranged on a Likert scale. The purpose of this study was to examine the effect of the benefits of brand image on satisfaction and loyalty in the context of color selection of cosmetic products. Five benefits of a brand image consisting of functional, social, symbolic, experience and appearance enhancements. The study was conducted on 97 women who showed functional improvement and appearance significantly affected loyalty. Four benefits of brand image, namely functional, social, experience, and appearance improvement are positively related to overall satisfaction. The results also show that overall satisfaction affects customer loyalty. The results show that marketers must focus on the benefits of brand image in their efforts to achieve customer loyalty.

\section{RESEARCH METHODOLOGY \\ Data and Sample Research}

The nature of this research is descriptive and verification, so the research method used is descriptive survey method and method explanatory survey. Quantitative data with data collection are related to the dependent or bound variable (satisfaction and loyalty of the Regional Office of Open University at Pangkalpinang students) and independent/ independent variables (service quality and image). The data source comes from primary data and secondary data.

The study population was all students who took the Face-to-face Tutorial who were studying higher education at the UT Pangkalpinang Regional Office during the registration period of 2017.2 which amounted to 3.675 students spread to the S1 Basic and Non-Basic Education Study Programs. To avoid questionnaire data with incomplete (broken) responses so that the number of samples needed to be increased is 35 samples. The total sample size of 235 respondents was taken using a simple sample determination by Malhotra (2005), which is multiplying the number of items observed with five (5) variables. The number of questionnaires examined was 40 x 5 so that a total sample of 235 was chosen to anticipate if a damaged questionnaire was obtained. The questionnaire used in this study was prepared using a Likert scale. According to Kinnear (Husein 1999) "The Likert scale is related to one's attitude towards something". Each question in the questionnaire has five (5) alternative answers. 5 Strongly Agree, 4 Agree, 3 Doubtful, 2 Disagree, 1 Strongly Disagree.

\section{Research Concept}

This research was conducted based on previous research by Ghozali (2010), Stephen, Maznah, Nabsiah \& Ismail (2007), Bloemer, Ruyter \& Peeters (1998), Prasetyaningrum(2009), Hossain and Shirley (2009), Hui \& Shun (2006), Sugihartono (2009), The purpose of this study was to investigate service quality variables, image, satisfaction and loyalty. The hypothesis is proposed as follows.

H1: Service quality positively affects student satisfaction.

H2: Image positively affects student satisfaction.

H3: Service quality positively influences student loyalty.

H4: Images positively influence student loyalty.

H5: Student satisfaction positively influences student loyalty.

H6: Service and Image Quality positively influences student loyalty.

H7: Service quality, image, and student satisfaction simultaneously influence student loyalty. 
H8: Student Satisfaction through Service Quality positively influences student loyalty.

H9: Student Satisfaction through Institutional Image positively influences student loyalty.

The research model can be seen in Figure 1 below.

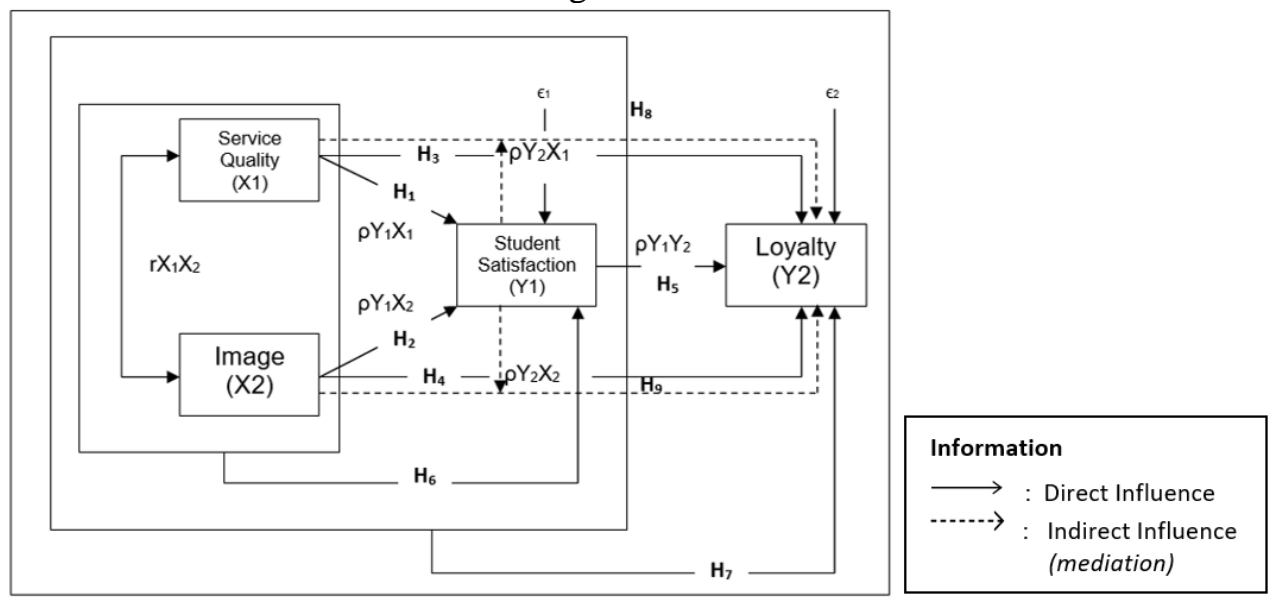

Figure 1 Research Model

\section{Variables and Measurements}

Based on the literature review, the researcher performed a variety of sub-variables on service quality variables by dividing them into five dimension groups namely Tangibles, Empathy, Reliability, Responsiveness, Assurance. Variable Image, variable satisfaction student, and variable loyalty student.

The Variable Operationalization List can be seen in Table 1 below.

Table 1 Operational List of Variables

\begin{tabular}{|c|c|c|c|}
\hline Variables & $\begin{array}{c}\text { Sub } \\
\text { Variables }\end{array}$ & Indicators Evaluation & Code \\
\hline \multirow{21}{*}{ Services } & Tangible & 1. Tutorial Locations and strategic offices. & BL1 \\
\hline & & 2. The extent of Tutorial parking area \& Regional office & BL2 \\
\hline & & facilities. & BL3 \\
\hline & & 3. Complete Tutorial facilities and Regional office. & BL4 \\
\hline & & 4. Modernization of learning equipment. & BL5 \\
\hline & & 5. Information facilities. & \\
\hline & Empathy & 1. Ability to handle complaints & EM1 \\
\hline & & 2. Patience helps complaints & EM2 \\
\hline & & 3. Clarity of information provided. & EM3 \\
\hline & & 4. Understanding of receiving UT instructions. & EM4 \\
\hline & & 5. Ease of communication. & EM5 \\
\hline & Reliability & 1. Speed in handling problems. & TE1 \\
\hline & & 2. Ability to handle problems. & TE2 \\
\hline & & 3. The discipline of tutors and Regional office officers. & TE3 \\
\hline & & 4. Tutor routines control problems. & TE4 \\
\hline & & 5. Ease of student administration procedures. & TE5 \\
\hline & Responsive & 1. Readinesstutors and officers to be contacted. & DT1 \\
\hline & ness & 2. The attention of tutors and Regional officers. & DT2 \\
\hline & & $\begin{array}{l}\text { 3. Ease of students to discuss with face-to-face tutorial } \\
\text { tutors and Regional officers. }\end{array}$ & DT3 \\
\hline & & $\begin{array}{l}\text { 4. The accuracy of face-to-face tutorial tutors and } \\
\text { Regional office officers in handling student problems. }\end{array}$ & DT4 \\
\hline & & 5. Concern for face-to-face tutorial tutors and Regional & DT5 \\
\hline
\end{tabular}




\section{SERVICES QUALITY AND IMAGES: SATISFACTION AND LOYALTY OF STUDENTS FACE TO FACE TUTORIAL SERVICES}

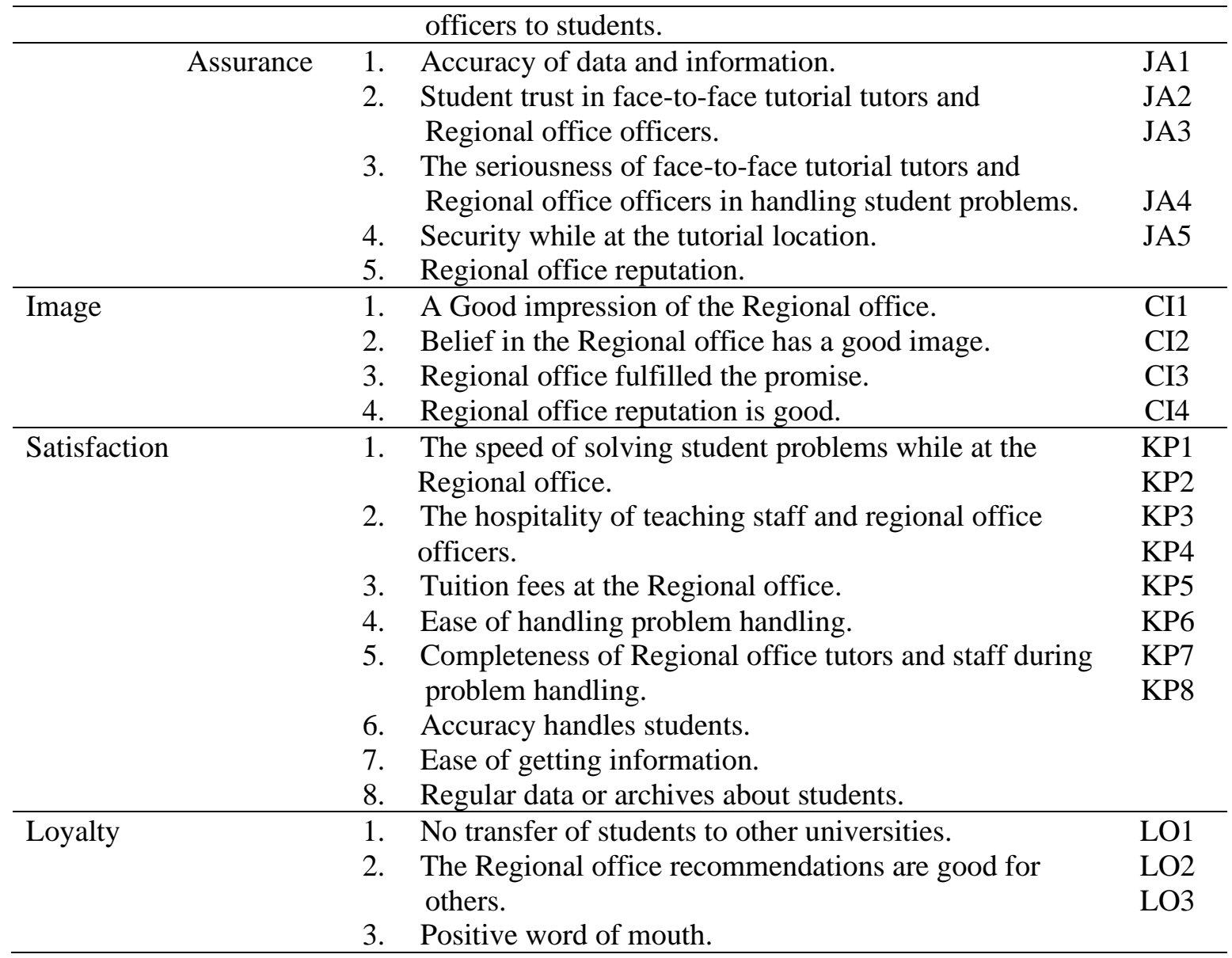

\section{Data Analysis Model}

In this study, qualitative data analysis is in-depth to describe the results of research through non-numerical or non-statistical approaches by using validity tests by measuring validity by seeing the value of the item to total correlation as valid if it is worth $\geq 0,30$ (Sekaran, 2011; Sugiyono, 2004). The choice of $\pm 0,30$-factor loadings is also more related to practical significance because the load factor above 0,30 is considered significant at $p=0,05$ (Heir, et al., (Abdullah 2005). Reliability testing can be done by measuring the value internal known consistency of the value of Cronbach Alpha $(\alpha)$. Cronbach Alpha $(\alpha)$ value that is implied for an instrument is reliable $\geq 0,60$ (Sekaran, 2011).

Quantitative analysis is done using path analysis. This analysis is used to determine the extent of the direct and indirect influence of Service Quality (X1), Image (X2) on Student Satisfaction (Y1) and its implications for Student Loyalty (Y2). The analysis is carried out through [1] testing the relationship between sub-variables, [2] path Analysis Equation Structure $1 \quad Y_{1}=\rho Y_{1} X_{1} X 1+\rho Y_{1} X_{2} X_{2}+\rho Y_{2} Y_{1}+\rho Y_{1} €_{1} €_{1}$, which determines the influence of research variables as a whole obtained from the sum of all exogenous variables endogenous variables. [3] path Structure II equation $\mathrm{Y}_{2}=$ $\rho Y_{2} X_{1} X 1+\rho Y_{2} X_{2} X_{2}+\rho Y_{2} Y_{1}+\rho Y_{2} \epsilon_{2} \epsilon_{2}$, which determines the influence of research variables as a whole obtained by the value of the path coefficient of the sum of all exogenous variables towards endogenous variables. [4] Path Analysis diagram, and [5] Calculation of Influence on Structure I and Structure II.

Statistical techniques used to test hypotheses using F Test (Simultaneous Testing) and t-test are used to test the constants of each independent variable individually and the Multiple Determination Coefficient $\left(\mathrm{R}^{2}\right)$ to measure the contribution of the independent variables studied to the dependent variable. 


\section{RESULTS}

The results of the analysis show that the overall variables in this study have high mean values, namely in the categories 3,41-4,20. And the image variable has the highest average value of 3.89. And in general, the factors of service quality, image, student satisfaction and loyalty of Regional Office of Open University at Pangkalpinang students are highly valued.

Validity tests are used to measure the validity or validity of a questionnaire. The minimum requirement to be considered as a valid instrument is the index value of its validity (value Pearson Correlation) has $r_{\text {count }}>r_{\text {table }}$ which is 0,137 . The results of the validity test in this study all have a $r_{\text {count }}$ value that is greater than $r_{\text {table }}$ so that the whole item of the research instrument is said to be valid.

The Variable Reliability test results can be seen in Table 2 below.

Table 2 Test Results from The reliability

\begin{tabular}{ccl}
\hline \multicolumn{1}{c}{ Variable } & $\begin{array}{c}\text { Chronchbach } \\
\text { Alpha }\end{array}$ & Description \\
\hline Service Quality (X1) & & \\
\hline Tangible & 0,688 & Reliable \\
\hline Emphaty & 0,744 & Reliable \\
\hline Reability & 0,784 & Reliable \\
\hline Responsiveness & 0,722 & Reliable \\
\hline Assurance & 0,770 & Reliable \\
\hline Image (X2) & 0,789 & Reliable \\
\hline Satisfaction (Y1) & 0,807 & Reliable \\
\hline Loyalty (Y2) & 0,606 & Reliable \\
\hline
\end{tabular}

Based on Table 2. where the reliability test results show that all variables have coefficient Chronchbach Alpha a large enough which is above 0,60 so that it can be said that all measuring concepts of each variable from the questionnaire are reliable which means that the questionnaire used in this study is a questionnaire reliable.

Hypothesis testing is done to see the effect of variable independent on the dependent variable. The $\mathrm{F}$ test shows whether all the independent variables included in the model have a significant influence on the dependent variable (Ghozali, 2005). To determine the $\mathrm{F}$ test by looking at the significance level of $5 \%(\alpha=0,05)$. If the value of $\operatorname{sig}<$ value $\alpha=0,05$ then Ha is accepted. If the value of sig $>$ value $\alpha=0,05$ then $\mathrm{Ha}$ is rejected.

The result of the F test structure 1 can be seen in Table 3 below.

Table 3 F Test Results Structure 1

ANOVA $^{\mathrm{a}}$

\begin{tabular}{|c|c|c|c|c|c|c|}
\hline \multicolumn{2}{|c|}{ Model } & $\begin{array}{c}\text { Sum of } \\
\text { Squares }\end{array}$ & df & $\begin{array}{l}\text { Mean } \\
\text { Square }\end{array}$ & \multirow{2}{*}{$\begin{array}{l}\mathrm{F} \\
94,824\end{array}$} & \multirow{2}{*}{$\begin{array}{l}\text { Sig. } \\
.000^{\mathrm{b}}\end{array}$} \\
\hline 1 & Regression & 2050,227 & 2 & $\begin{array}{r}1025,11 \\
3\end{array}$ & & \\
\hline & Residual & 2183,754 & 202 & 10,811 & & \\
\hline & Total & 4233,980 & 204 & & & \\
\hline
\end{tabular}

a. Dependent Variable: Total Satisfaction

b. Predictors: (Constant), Total Image, Total Service Quality

Table 3. The results of the $F$ test can be seen the significance value of 0,000 is much smaller than 0,05. Then the regression model can be used to predict student satisfaction variables or in other words, exogenous variables of service quality and image together (simultaneous) have a significant effect on student satisfaction. 
The result of F Test Results Structure 2 can be seen in Table 4 below.

Table 4 F Test Results Structure 2

ANOVA $^{\mathrm{a}}$

\begin{tabular}{lcrrrr}
\hline Model & Sum of & & & & \\
Squares & \multicolumn{1}{c}{ df } & Mean Square & \multicolumn{1}{c}{ F } & \multicolumn{1}{c}{ Sig. } \\
\hline Regression & 508,652 & 3 & 169,551 & 129,409 & $.000^{\mathrm{b}}$ \\
Residual & 263,348 & 201 & 1,310 & & \\
Total & 772,000 & 204 & & & \\
\hline
\end{tabular}

a. Dependent Variable: Total Loyalty Image

b. Predictors: (Constant), Total Satisfaction, Total Service Quality, Total

Table 4. The results of the $\mathrm{F}$ test can be seen the significance value of 0,000 is much smaller than 0.05 . Then the regression model can be used to predict student loyalty variables or in other words, exogenous variables of service quality, student image, and satisfaction together (simultaneous) have a significant effect on student loyalty.

The t-test is used to determine the relationship between the Independent variable on the Dependent variable. Criteria for acceptance of hypotheses are as follows: [1] Zero hypothesis $\left(\mathrm{H}_{0}\right)$ is accepted if the value of $\operatorname{sig}>$ value $\alpha$ and vice versa if the value of $\operatorname{sig}<$ value $\alpha$ then null hypothesis is rejected, [2] Alternative hypothesis $\left(\mathrm{H}_{\mathrm{a}}\right)$ is accepted if the value is sig<value $\alpha$ and vice versa if the value of sig $>$ value $\alpha$, the Alternative hypothesis $\left(\mathrm{H}_{\mathrm{a}}\right)$ is rejected.

The results of t-test Results Structure 1 can be seen in Table 5 below.

Table 5 T-Test Results Structure 1

Coefficients $^{\mathrm{a}}$

\begin{tabular}{|c|c|c|c|c|c|}
\hline \multirow{2}{*}{ Model } & \multicolumn{2}{|c|}{$\begin{array}{l}\text { Unstandardized } \\
\text { Coefficients }\end{array}$} & \multirow[t]{2}{*}{$\begin{array}{c}\text { StandardizedC } \\
\text { Coefficients }\end{array}$} & \multirow{2}{*}{ 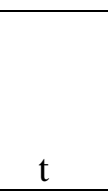 } & \multirow{2}{*}{ Sig. } \\
\hline & & d.Erro & & & \\
\hline (Constant) & 5.065 & 1.902 & & 2.663 & .008 \\
\hline $\begin{array}{l}\text { Total Services } \\
\text { Quality }\end{array}$ & .638 & .128 & .324 & 4.975 & .000 \\
\hline Total Image & .780 & .115 & .444 & 6.812 & .000 \\
\hline
\end{tabular}

a. Dependent Variable: Total Satisfaction

From the results of processing data in Table 5. Obtained [1] Effect of service quality on student satisfaction, that is on the variable quality of service significance value $0,000<0,05$. So the hypothesis that reads there is significant influence between the quality of service on student satisfaction is accepted $\left(\mathrm{H}_{\mathrm{a}}\right.$ accepted and $\mathrm{H}_{\mathrm{o}}$ rejected). This means that part there is a significant effect between service quality and student satisfaction. [2] Effect of an image on student satisfaction, that is, on image variables, a significance value of $0,000<0,05$. So the hypothesis that reads there is significant influence between the image of student satisfaction is accepted $\left(\mathrm{H}_{\mathrm{a}}\right.$ accepted and $\mathrm{H}_{\mathrm{o}}$ rejected). This means that part there is significant influence between image and satisfaction.

The results of t-test Results Structure 2 can be seen in Table 6 below. 
Table 6 T-Test Results Structure 2

Coefficients $^{\mathrm{a}}$

\begin{tabular}{|c|c|c|c|c|c|}
\hline \multirow[b]{2}{*}{ Model } & \multicolumn{2}{|c|}{$\begin{array}{c}\text { Unstandardized } \\
\text { Coefficients }\end{array}$} & $\begin{array}{c}\text { StandardizedC } \\
\text { oefficients }\end{array}$ & \multirow[b]{2}{*}{$\mathrm{T}$} & \multirow[b]{2}{*}{ Sig. } \\
\hline & B & $\begin{array}{c}\text { Std. } \\
\text { Error }\end{array}$ & Beta & & \\
\hline (Constant) & .894 & .674 & & 1.327 & .186 \\
\hline $\begin{array}{l}\text { Total Services } \\
\text { Quality }\end{array}$ & .010 & .047 & .012 & .206 & .837 \\
\hline Total Image & .023 & .044 & .031 & .525 & .600 \\
\hline Total Satisfaction & .352 & .024 & .824 & 14.373 & .000 \\
\hline
\end{tabular}

a. Dependent Variable: Total Loyalty

From the results of processing data in Table 6. Obtained [1] Effect of service quality on student loyalty, namely the variable quality of service significance value $0,837>0,05$. So the hypothesis that reads there is a significant effect between the quality of service on student loyalty is rejected $\left(\mathrm{H}_{\mathrm{a}}\right.$ is rejected and $\mathrm{H}_{\mathrm{o}}$ is accepted). This means that part there is no significant effect between service quality and student loyalty. [2] Effect of an image on student loyalty, namely on the image variable of significance value $0,600>0,05$. So that the hypothesis that reads there is significant influence between the image of student loyalty is rejected $\left(\mathrm{H}_{\mathrm{a}}\right.$ rejected and $\mathrm{H}_{\mathrm{o}}$ accepted). This means that part there is no significant influence between image and loyalty.

Effect of student satisfaction on student loyalty. In the variable student satisfaction the significance value is $0,000<0,05$. So the hypothesis that reads there is a significant effect between student satisfaction on student loyalty is accepted $\left(\mathrm{H}_{\mathrm{a}}\right.$ accepted and $\mathrm{H}_{\mathrm{o}}$ rejected). This means that part there is a significant effect between student satisfaction and student loyalty.

\section{DISCUSSION}

\section{Influence of Service Quality on Student Satisfaction}

Hypothesis testing shows that directly the quality of service influences and significantly affects student satisfaction face-to-face tutorial of Regional Office of Open University at Pangkalpinang $(0,000<0,05)$. Can be explained, the better the quality of services provided, the more satisfaction will be felt by students.

\section{Influence of Institutional Image on Student Satisfaction}

Hypothesis testing shows that directly the institutional image has a significant effect on the satisfaction of students in face-to-face tutorials of Regional Office of Open University at Pangkalpinang $(0,000<0,05)$. This shows that by attaching a good image of the institution that is embedded in the minds of students, the satisfaction felt by students will be even higher.

\section{Influence of Service Quality on Student Loyalty}

Hypothesis testing shows that service quality has a positive but not significant effect on face-to-face student loyalty of Regional Office of Open University at Pangkalpinang $(0,837>0,05)$. Service quality that is fulfilled properly can affect student loyalty but is not significant because there are other factors that affect loyalty more than service quality. If the company is able to provide the quality of service expected by students, it will lead to student loyalty behavior, but it is necessary to pay attention to other factors.

\section{Influence of Image of Institution on Student Loyalty}

Hypothesis testing shows that institutional image has a positive but not significant effect on face-to-face student loyalty in UPBJJ-UT Pangkalpinang $(0,600>0,05)$. That is, the positive image of the institution in the minds of students face to face tutorials of 


\section{SERVICES QUALITY AND IMAGES: SATISFACTION AND LOYALTY OF STUDENTS FACE TO FACE TUTORIAL SERVICES}

Regional Office of Open University at Pangkalpinang is able to maintain student loyalty but is not significant because there are other factors that affect loyalty more than the image of the institution. It can be concluded that the more embedded the image of a positive institution in the mind, the higher the loyalty of students but it is necessary to pay attention to other factors.

\section{Influence of Student Satisfaction on Student Loyalty}

Hypothesis testing shows that directly student satisfaction has a positive and significant effect on face-to-face student loyalty tutorial of Regional Office of Open University at Pangkalpinang $(0,000<0,05)$. The more satisfaction felt by students, the higher the sense of loyalty generated by students.

\section{Influence of Service Quality and Institutional Image on Student Satisfaction}

Hypothesis testing shows that jointly a positive and significant effect on face-toface tutorial student satisfaction of Regional Office of Open University at Pangkalpinang $(0,000<0,05)$. So it can be concluded that the increasing service and image of the institution owned by of Regional Office of Open University at Pangkalpinang and able to be felt by students will further increase the sense of satisfaction generated by students.

Influence of Service Quality, Institutional Image and Satisfaction on Student Loyalty

Tests on service quality, institutional image and student satisfaction together on student loyalty shows that together service quality, institutional image and student satisfaction have a positive and significant effect on student loyalty of Regional Office of Open University at Pangkalpinang $(0,000<0.05)$ So it can be concluded that the better the quality of service, the image of the institution and the satisfaction felt by students, will increase the sense of loyalty generated by students.

\section{Influence of Service Quality on Student Loyalty through Student Satisfaction}

The value of the direct effect is smaller than the indirect effect $(0,000144<$ 0.2669976). It can be concluded, satisfaction is able to mediate the relationship of service quality and student loyalty. The influence of service quality through satisfaction is greater than the direct effect on loyalty. These results indicate that service quality has an indirect effect on loyalty through satisfaction or it can be concluded that satisfaction can be a variable that mediates service quality on loyalty.

Influence of Institutional Image on Student Loyalty through Student Satisfaction

The value of the direct effect is smaller than the indirect effect $(0,000961$ < 0.365856). It can be concluded, satisfaction is able to mediate the relationship between the image of the institution and student loyalty. The effect of mediating student satisfaction is greater than the direct effect of the institution's image on loyalty. These results indicate that the image of an institution has an indirect effect on loyalty through satisfaction or it is concluded that satisfaction can be a variable that mediates between the image of an institution against loyalty.

\section{CONCLUSION}

This study was conducted to capture students' perceptions of Service Quality and Image on Student Satisfaction to Increase Student Loyalty Face-to-Face Tutorial Services that took part in a tutorial service Regional office of Open University at Pangkalpinang. The study was conducted on 235 students. Questionnaires that can be processed are 205 using the Likert Scale. Based on the data and discussion, the results obtained that the overall variables in this study have a high average value that is in the categories 3,41-4,20. And the image variable has the highest average value of 3,89. And in general, the factors of service quality, image, student satisfaction and loyalty of Regional office of Open University at Pangkalpinang students are highly valued. 1 correlation structure is obtained (R) 0,696 and the coefficient of determination $\left(R^{2}\right)$ $48,4 \%$, the rest (E) $51,6 \%$ influenced by other factors not examined. While the correlation test 2 structure is obtained (R) 0,812 and the coefficient of determination $\left(R^{2}\right)$ of $65,9 \%$, the rest (E) $34,1 \%$ influenced by other factors not examined. 
The results obtained directly that the service quality and image of each have a significant effect on student satisfaction, service quality, and each image has no significant effect on student loyalty, and student satisfaction has a significant effect on student loyalty. Indirectly the results that service quality and image mediated by student satisfaction each have no significant effect on student loyalty. Simultaneously the results obtained that service quality and image have a positive and significant influence on student satisfaction. As well as the quality of service, student image and satisfaction have a positive and significant influence on student loyalty.

Every increase or decrease in student satisfaction will indirectly influence student loyalty and every time there is an increase or decrease in service quality, student image and satisfaction together will have a significant effect on student loyalty to Regional office of Open University face-to-face tutorial service in Pangkalpinang. Institutions further enhance service quality variables and institutional image so that Regional Office of Open University at Pangkalpinang satisfaction and loyalty is even better.

\section{References}

Ali, F., Hussain, K., \& Ryu, K. (2017). Resort hotel service performance (RESERVE) - an instrument to measure tourists' perceived service performance of resort hotels. Journal of Travel \& Tourism Marketing, 34 (2), $\underline{556}-\underline{569}$.

Andreassen, T. W. (1994). Satisfaction, Loyalty, and Reputation as Indicators of Customer Orientation in the Public Sector. International Journal of Public Sector Management, 7 (2), 16-34.

Bakar, A. R. A., Talib, A. N. A., \& Hashim, F. (2014). Restoring service quality, satisfaction, and loyalty in higher education institutions through market orientation. J. Global Business Advancement, 7 (1), 88-107.

Blackwell, R.D., Miniard, P.W., Engel, J. F. (2005). Consumer Behavior. Harcourt, Inc Sea Harbor Drive: Orlando Florida.

Bloemer, J., Ruyter, K.D., \& Peeters, P. (1998). Investigating drivers of bank loyalty : the complex relationship between image, service quality and satisfaction. International Journal of Bank Marketing, 16 (7), 276-286.

Darojat, O. (2018). How are the results of quality assurance programs used to inform practices at a distance higher education?. Turkish Online Journal of Distance Education, 19 (1), 75-88.

Ghozali, I. (2005). Aplikasi Analisis Multivariate Dengan Program SPSS. Ed. 4. Semarang: Badan Penerbit Universitas Diponegoro.

Ghozali, I. (2010). Analisis Kualitas Jasa Pendidikan dan Pengaruhnya Terhadap Loyalitas Mahasiswa Pada Perguruan Tinggi Swasta (PTS) Di Kota Semarang. Jurnal Media Ekonomi dan Manajemen, 21 (1), 89-101.

Harsasi, M., \& Sutawijaya, A. (2018). Determinants of student satisfaction in the online tutorial: A study of a distance education institution. Turkish Online Journal of Distance Education, 19 (1), 89-99.

Kensbock, S. L., Patiar, A., \& Jennings, G. (2017). Hotel room attendants' delivery of quality service. Tourism and Hospitality Research, 0 (0), 1-12. 
Kotler, P \& Armstrong, G. (2014). Principle Of Marketing, 15th edition. New Jersey: Pearson Prentice Hall.

Khoo, S., Ha, H., \& McGregor, S. L. T. (2017). Service quality and student/customer satisfaction in the private tertiary education sector in Singapore. International Journal of Educational Management, 31 (4), 430-444.

Lo. C.C. (2010). How student satisfaction factors affect perceived learning. Journal of the Scholarship of Teaching and Learning, 10 (1), 47-54.

Lupiyoadi, R \& Hamdani. (2008). Manajemen Pemasaran Jasa. Jakarta: Salemba Empat.

Malhotra, N K. (2005). Riset Pemasaran: (Pendekatan Terapan). Alih Bahasa Indonesia oleh : Soleh Rusyadi M. PT. Indeks Kelompok Gramedia: Jakarta.

Nguyen, N., \& LeBlanc, G. (2001). Image and reputation of higher education institutions in students' retention decisions. International Journal of Educational Management, 15(6), 303-311.

Omar, M. S., Ariffin, H. F., \& Ahmad, R. (2016). Service Quality, Customers' Satisfaction and the Moderating Effects of Gender: A Study of Arabic Restaurants. Procedia - Social and Behavioral Sciences, 224 (2016), 384-392.

Parasuraman, A., Zeithaml, V., \& Berry, L.L. (1995). A Conceptual Model of Service Quality and Its Implications for Future Research.Journal of Marketing, 49 (1), 86101.

Parasuraman, A P., Zeithaml, V A., \& Malhotra, A. (2005). E-S-Qual: A Multiple-Item Scale for Assessing Electronic Service Quality, Journal of Service Research, 7 (3), 213-233.

Prasetyaningrum, I. D. (2009). Analisis Pengaruh Pembelajaran Dan Kualitas Pelayanan Terhadap Kepuasan Mahasiswa Dan Loyalitas Mahasiswa (Studi Kasus Pada Undaris Ungaran). Jurnal Industrial Mangement. 25 (3), 123-136.

Purwaningdiyah. (2010). Borang UPBJJ-UT dalam rangka Akreditasi Program Studi Universitas Terbuka. Padang: UPBJJ-UT Padang.

Saleh, M A., Quazi, A., Keating, B., \& Gaur, S.S. (2016). Quality and Image of Banking Services A Comparative Study of Conventional and Islamic bank. International Journal of Bank Marketing, 34 (5), 623-648.

Stephen, L.S., Maznah, W.O., Nabsiah, A.W \& Ismail, I. (2007), The Effect of Brands on Overall Satisfaction and Loyalty Intention in the Context of Color Cosmetic. Asian Academy of Management Journal, 12 (1). 83-107.

Sugandini, D. (2003). Anteseden Loyalitas Konsumen pada industri Perhotelan Studi pada Hotel berbintang di daerah Istimewa Yogyakarta. Jurnal Wahana ekonomi dan akuntansi, $6(8), 31-42$.

Sugihartono, J. (2009). Analisis Pengaruh Citra, Kualitas Layanan dan Kepuasan Terhadap Loyalitas Pelanggan (Studi Kasus pada PT. Pupuk Kalimantan Timur. Jurnal Industrial Mangement, 3 (8), 31-47. 
Susanto, H. (2014). Pengaruh Layanan Akademik Terhadap Kepuasan Mahasiswa Program Pascasarjana Universitas Terbuka Pada Unit Program Belajar Jarak Jauh (UPBJJ) Mataram. Jurnal Pendidikan Terbuka Dan Jarak Jauh, 15 (2), 88-98.

Tjiptono, F. (2014). Manajemen Jasa. Yogyakarta: Andi.

Wantara, P. (2016). Effect of Service Quality and Perceived Value Satisfaction and Loyalty Religious Tourists Visit Island Madura, Indonesia. Journal AFEBI Management and Business Review, 1 (1), 55-64

Yusuf. (2018). The Influence of Quality Academic Service on Student Satisfaction (Empiric Study on Bidikmisi Scholarship Student Regional Office of Universitas Terbuka at Pangkalpinang, Indonesia). Integrated Journal of Business and Economics, 2 (2), 40-56.

Zeithaml, V., Bitner, M.J., \& Gremler, D. (2006). Service Marketing. McGraw-Hill Companies: United States. 